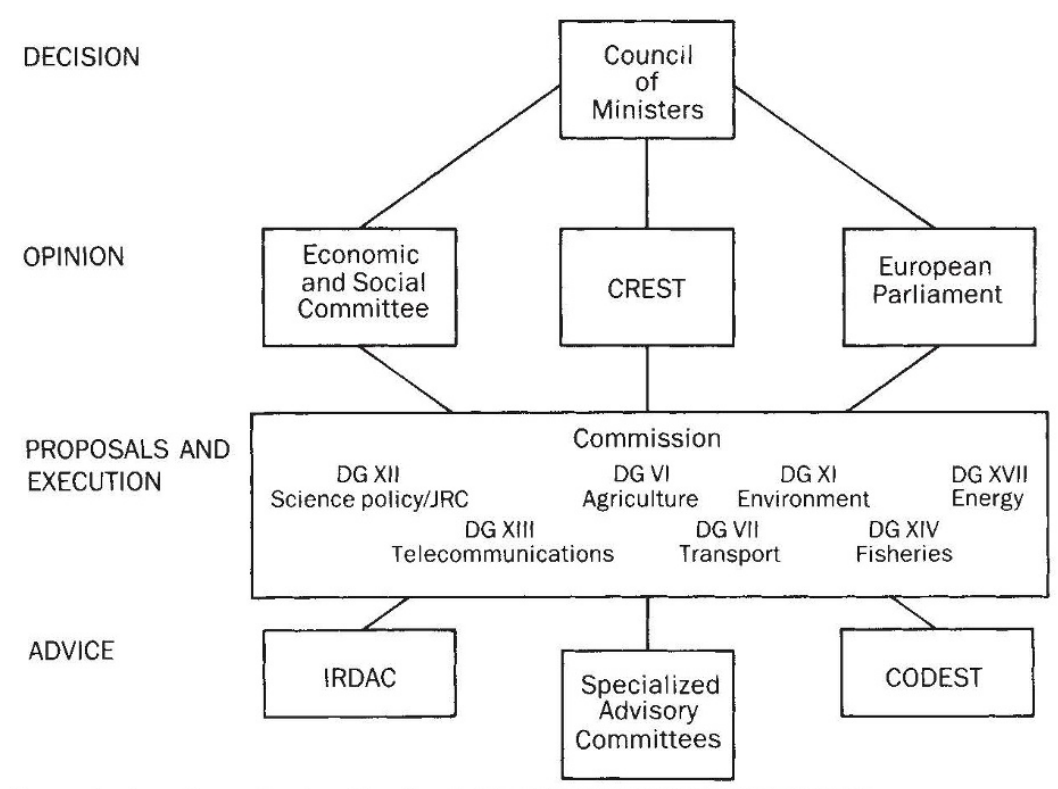

Commissions in context - the structure of the European bureaucracy.

directed towards the support of its domestic industries.

So far, the Commission appears rather to have concentrated on the development of its own research policy, which is at present a corporate issue spanning at least three of the directorates-general - those responsible for research, industry and environment. Of these, that responsible for research, known as DGXII (pronounced "Dee-Gee-Twelve") plays a crucial role, both as a prime mover behind the five-year 'Framework' programme now half completed, and as the small and only source of support for basic research.

So how fair is the charge of "bureaucrat"? There is no simple answer. But the popular European view that Brussels is filled with a huge army of civil servants bent on interference is wide of the mark. The staff of 17,000 might be held to be small, given the need to administer such a variety of policies in a dozen countries speaking eight acknowledged languages.

The legalism of the Commission's procedures, especially in the drafting of its directives, is probably unavoidable given their force as trans-national legal instruments. The triviality of some of the issues dealt with (the definition of ice-cream, for example) probably reflects the influence of parochial lobbies (to which Brussels is prone), but might be avoided by clearheaded forward planning.

No doubt the directorates-general differ, but first impressions do not suggest that the senior people have a bureaucratic caste of mind. Many of them are Europeans impatient for more rapid progress towards a united Europe. Within a directorate, at least, there is also room for flexibility; DGXII, for example, is frequently able to make small grants of money to help organize meetings on issues that may lead to some collaboration. Nor do the Commission's dealings with the outside world fairly suggest that armies of

pernickety people have deliberately designed forms so complicated as to deter respondents from completing them. On the contrary, the Commission's more common failing is that too much of what it does is done with too much haste, often reflecting people's eagerness to see that money is spent as soon as the appropriate budget has been approved.

Yet there is a sense in which Brussels is a bureaucracy in the worst sense, perhaps unavoidably. The Commission as a whole does not have the flexibility, enjoyed by elected governments, to second-guess IMITATIONS

\section{London}

PosT-war interests in cooperation have littered Europe with international organizations which are often confused with the EEC. Here is a brief guide to them:

- The Council of Europe is a strictly European organization meant to foster collaboration in the fields of law and social policy (which may include, for example, the regulation of research). There are now 26 members. Its chief functions are to negotiate international conventions, which have the force of law in member states; the best-known is the Convention on Human Rights, signed in 1950, accompanied by a European Court of Human Rights which hears complaints by individuals against their governments on the recommendation of the European Commission on Human Rights. The council's headquarters are in Strasbourg.

- The Organization for Economic Cooperation and Development or OECD began life as the Organization for European Economic Cooperation. The name was changed in 1961 with the accession of the United States and Canada and, at a later stage, Japan and Australia. Outside the

\title{
Those things that the EEC is not
}

their electors, shifting resources in this direction or that as circumstances change. Line-item budgetary control is implicit in everything its political masters allow it to do. Worse, the commission's own procedures are not as coherent as they should be.

For such a young organization as the Commission (or perhaps precisely for that reason), the directorates-general are surprisingly jealous of each other's powers of decision. This is the mechanism by which the Commission appears frequently to reach nonsensical and corrosive decisions on questions such as the use of hormones in growing beef cattle; the power of decision lay with those responsible for agriculture and environment, who chose not to consult those in DGXII who would certainly have known better.

The question whether Brussels might arrange to seem less bureaucratic is a question of its own deportment. Of necessity, the mostly intelligent and frequently idealistic people working for the Commission differ from those working for national governments in their conviction that the destiny of Europe is to be united. They naturally regard the member governments as entities that must be helped, and sometimes hectored, to share the same vision; with the passage of 30 years, their signature of the Treaty of Rome seems to count for little in Brussels now. Could that be why there seems always to be at least one, and sometimes several, among the member governments which is or are uneasy with the process they began? field of economics, OECD has a section of science and technology best-known for its collections of statistics on scientific manpower and spending and for its occasional reviews of national science policies. OECD also operates the Nuclear Energy Agency and the International Energy Agency. The organization is based in Paris.

- The Western European Union is a treaty between seven governments, including Canada and the United States, which among other things is the forum in which the West German government has undertaken never to make nuclear weapons and in which Britain and the United States have undertaken to maintain armed forces in mainland Europe. The headquarters are in London.

- EUREKA is the organization set up on a French initiative in $\mathbf{1 9 8 5}$ to arrange for European collaboration on the development of marketable products. Originally advocated as a mechanism for stimulating European industry because, at the time, it was suspected that US industry would be stimulated by the Strategic Defense Initiative (SDI), Eureka now has an administration based in Brussels 